\title{
The Bambui Health and Aging Study (BHAS): factors associated with the treatment of hypertension in older adults in the community
}

\author{
Projeto Bambuí: fatores associados \\ ao tratamento da hipertensão arterial \\ entre idosos na comunidade
}

Josélia Oliveira Araújo Firmo 1,2

Sandhi Maria Barreto 2

Maria Fernanda Lima-Costa 2

\footnotetext{
1 Escola Nacional de Saúde Pública, Fundação Oswaldo Cruz. Rua Leopoldo Bulhões 1480, Rio de Janeiro, $R \mathrm{~J}$ 21041-210, Brasil.

2 Núcleo de Estudos em Saúde Pública e Envelhecimento, Centro de Pesquisas René Rachou, Fundação Oswaldo Cruzl Universidade Federal de Minas Gerais Av. Augusto de Lima 1715, Barro Preto, Belo Horizonte, $M G$ 30190-002, Brasil. firmoj@cpqrr.fiocruz.br
}

\begin{abstract}
The objective of this study was to investigate the factors associated with the treatment of hypertension among older adults living in the community. All residents $(n=1,742)$ of Bambuí, Minas Gerais State, Brazil (15,000 inhabitants) aged $\geq 60$ years were selected, and 1494 (85.8\%) were interviewed and examined. Of these, 919 (61.5\%) were hypertensive, 704 were aware of their condition (study population), and 578 were under treatment. Only 38.8\% of the individuals under treatment presented controlled systolic and diastolic pressures $(<140$ and $<90 \mathrm{mmHg}$, respectively). Independent associations with treatment of hypertension were found for, in decreasing order of magnitude: less time elapsed since the last blood pressure measurement, greater number of physician visits in the past 12 months, higher body mass index, female gender, history of coronary disease, changes in diet due to arterial hypertension, and higher family income. Our results show that the factors most strongly associated with treatment of hypertension (use of health services) could be modified through adequate health policies for older adults.
\end{abstract}

Key words Aging Health; Hypertension; Continuity of Pacient Care

Resumo O objetivo deste estudo foi determinar os fatores associados ao tratamento da hipertensão entre idosos residentes na comunidade. Todos os residentes $(n=1.742)$ na cidade de Bambuí (15 mil habitantes) com $\geq 60$ anos foram selecionados; 1.494 (85,8\%) participaram do estudo. Desses, 919 (61,5\%) eram hipertensos; 704 sabiam ser hipertensos (população estudada), 578 estavam sendo tratados. Entre os tratados, somente 38,8\%, apresentavam pressão sistólica e diastólica controlada $(<140$ e $<90 \mathrm{mmHg}$, respectivamente). Associações independentes com o tratamento da hipertensão arterial foram encontradas, em ordem decrescente de magnitude, para menor tempo decorrido após a última medida de pressão arterial, maior número de consultas médicas nos últimos 12 meses, maiores índices de massa corporal, sexo feminino, história de doença coronariana, mudanças na alimentação por causa da hipertensão arterial e maior renda familiar. Nossos resultados mostram que os fatores mais fortemente associados com o tratamento da pressão arterial (uso de serviços de saúde), poderiam ser modificados por meio de políticas de saúde adequadas para a população idosa.

Palavras-chave Saúde do Idoso; Hipertensão; Continuidade da Assistência ao Paciente 


\section{Introduction}

Aging of the population is the most important demographic change observed in most countries worldwide, manifested not only by an increase in the absolute number of older adults but also in higher proportions of older adults in the overall population. It is a phenomenon that was initially observed in the developed world, but more recently developing countries have shown the highest rates of increase. It is estimated that by the year 2025, five of the 10 nations in the world with the highest numbers of older adults will be developing countries, including Brazil, with an estimated 31.3 million people aged 60 or over (IBGE, 2000; UN, 1985). An important consequence of the increase in the number of older adults in a population is that these individuals are more likely to present illnesses and/or chronic conditions that require more medical and social services. Arterial hypertension is one of the most frequent chronic conditions both in developed (De Backer et al., 1998; Freeman et al., 1996; Joffres et al., 1997; Prencipe et al., 2000; Satish et al., 1998; Stockwell et al., 1994; Trenkwalder et al., 1994) and developing countries (De Lena et al., 1995; Ibraim et al., 1995; Lima-Costa et al., 2001a; Piccini \& Victora, 1994; Srinivas et al., 1998; Trindade et al., 1998), and the prevalence of hypertension increases with age.

In Brazil, cardiovascular diseases constitute the principal cause of hospitalization and death among older adults, accounting for $38 \%$ of all deaths and $32 \%$ of hospitalizations in the public sector in 1996. Cerebrovascular disease and ischemic heart disease are the most frequent cardiovascular causes of death among older adults (mortality rates $=473.6$ and 428.5 per 100,000, respectively) (Lima-Costa et al., 2000a). Arterial hypertension is the main risk factor for coronary disease, congestive heart failure, cerebrovascular disease, aortic aneurysm, renal disease, and retinopathy among the elderly (Rudd et al., 1995; National High Blood Pressure and Education Program Working Group, 1994). Adequate treatment of arterial hypertension significantly reduces cardiovascular morbidity and mortality, especially among older individuals (Amery et al., 1985; Dalhof et al., 1991; MRC Working Party, 1992; SHEP Cooperative Research Group, 1991; Vokonas et al., 1988). Results of the Framingham Study, for example, showed that the risk of cardiovascular events attributable to arterial hypertension was two to three times greater in older individuals than in younger adults (Vokonas et al., 1988). However, few population-based studies have focused on the factors associated with the treatment of arterial hypertension among older adults (Satish et al., 1998).

The Bambuí Health and Aging Study (BHAS) is a population-based cohort study of older adults in the town of Bambuí, State of Minas Gerais, Brazil (Lima-Costa et al., 2000b). A high prevalence of uncontrolled blood pressure was observed among older adults ( $>60$ years of age) at baseline: $26 \%$ presented arterial systolic pressure $=140-159 \mathrm{mmHg}$ and $/$ or diastolic pressure $=90-99 \mathrm{mmHg}$ (stage 1 ), and $19 \%$ presented systolic pressure $\geq 160$ or diastolic pressure $\geq 100 \mathrm{mmHg}$ (stage 2) (Lima-Costa et al., 2001a). The present study is part of the BHAS baseline and was developed with the objective of determining the factors (socio-demographic, individual health indicators, life habits, health services utilization, use of medication, and access to private health care) associated with the treatment of arterial hypertension among older adults known to have hypertension.

\section{Methodology}

\section{Study area}

The municipality of Bambuí had 20,573 inhabitants in 1991, 15,032 (73\%) of whom lived in the town of Bambuí (IBGE, 1992). The principal causes of death in the municipality in 1996 were cerebrovascular diseases (CID-10: I60I69), Chagas disease (CID-10: B57), ischemic heart diseases (CID-10: I20-I25), and chronic obstructive pulmonary disease (mortality rates $=110.0,61.4,42.5$, and 18.9 per 100,000 , respectively) (Lima-Costa et al., 2001a). Bambuí was formerly an important endemic area for Chagas disease, and despite the fact that transmission of Trypanosoma cruzi has been interrupted for nearly 20 years, prevalence of infection remains high in the older adult population due to a cohort effect (Lima-Costa et al., 2001b).

\section{Study population}

A complete census of Bambuí town was conducted by our research team in November and December 1996 to identify study participants. All residents 60 years of age or over $(n=1,742)$ were selected to participate in the baseline of the cohort study. Standardized interviews, laboratory tests, blood pressure readings, anthropometric measurements, and electrocardiography were performed from January to August 1997. Blood pressure measurements were per- 
formed on 1494 individuals, corresponding to $85.8 \%$ of the older adult residents in the community. All participants in the BHAS baseline who were classified as hypertensive and were aware of their condition (Figure 1) were selected for the present study.

\section{Interview}

Interviews were conducted in participants' homes using the BHAS questionnaire. When the participant was unable to complete the interview due to a cognitive deficit or some other health problem, a proxy respondent was used. Interviewers were selected among residents of Bambuí with at least 11 years of formal education (Lima-Costa et al., 2000a).

The following information was included: (1) socio-demographic characteristics (age, gender, marital status, whether living alone, and monthly family income); (2) presence of an informal care-giver; (3) history of medical diagnosis of diseases or selected chronic conditions (has a doctor ever told you that you had), such as hypertension, diabetes, angina pectoris, or myocardial infarction; (4) family history of cardiovascular diseases under 50 years of age; (5) habits (current smoking status, daily consumption of fruit and vegetables in the last 12 months, and physical activity during leisure time in the last 90 days); (6) changes in habits due to arterial hypertension in the last 12 months (weight control or diet changes); (7) use of medication for treatment of hypertension in the last 90 days (beta-blockers, diuretics, calcium channel blockers, angiotensin-converting enzyme (ACE) inhibitors, ACE antagonists, central alpha-blockers, and/or vasodilators); (8) number of medications used in the last 90 days, excluding antihypertensive medication (with or without a physician's prescription); (9) utilization of health services in the last 12 months (number of medical consultations, number of hospital admissions, time elapsed since last blood pressure measurement); and (10) access to a private health care plan.

\section{Blood pressure measurements}

Blood pressure measurements were conducted at the Emmanuel Dias Extension Unit of the Oswaldo Cruz Foundation in Bambuí, using standardized equipment (portable sphygmomanometers: Tyco 5097-30, United States; and stethoscopes: Littman Cardiology II, United States). Technicians were trained at the School of Medicine of the Federal University in Minas Gerais by physicians with experience in inves-

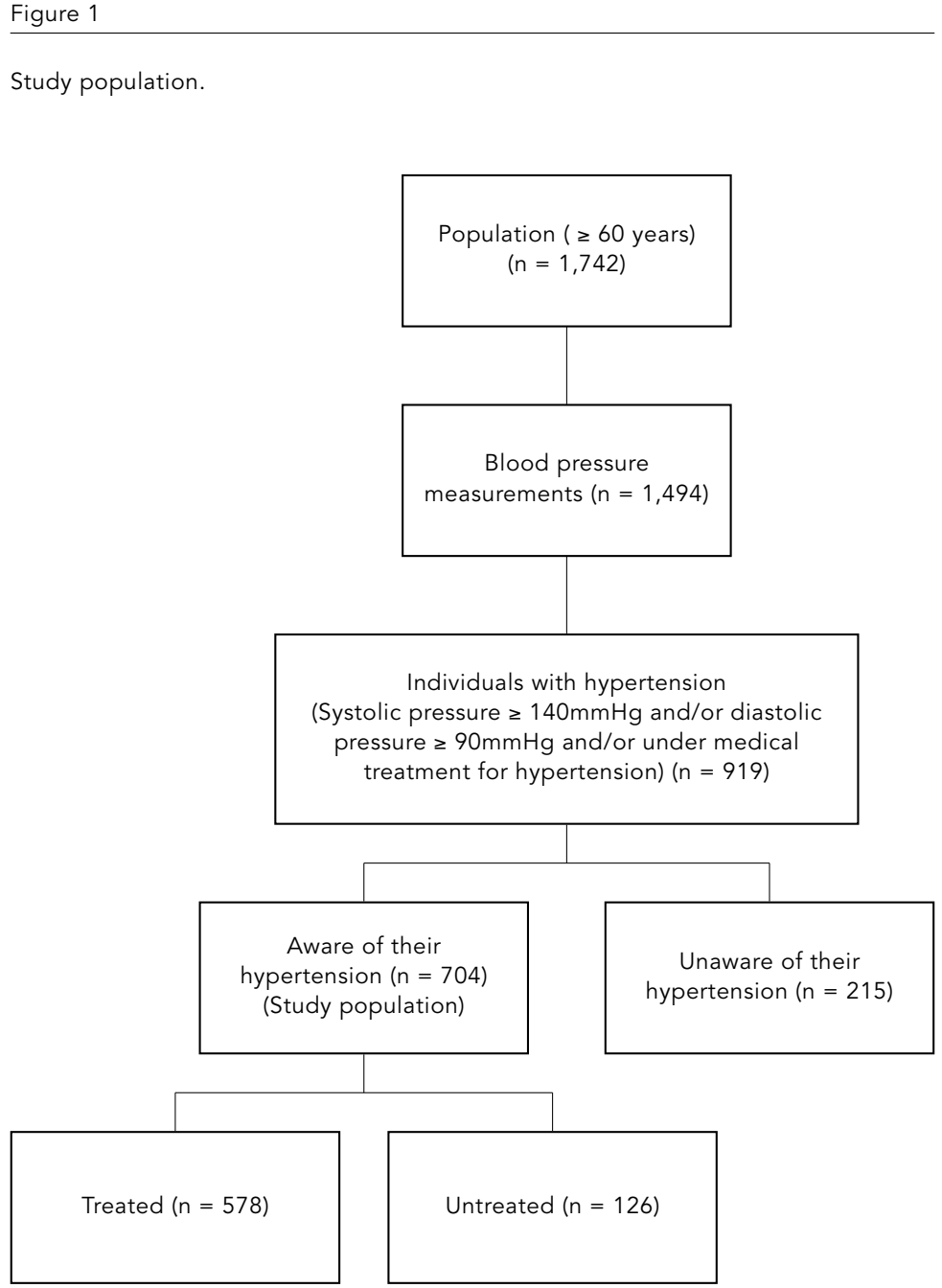

tigating hypertension in the community. Training included instruction in the use of a video, breathing measurements, and exercises to minimize inter-and intra-observer variability.

Three blood pressure measurements were performed at two-minute intervals, with the individual seated and the arm resting at heart level. Measurements were performed in a quiet, isolated area with controlled room temperature. The first measurement was taken at least 30 minutes after the last cigarette (in the case of smokers) and/or cup of coffee and after at least 5 minutes of initial rest. Diastolic and systolic blood pressures used the mean of the second and third measurements (JNC, 1993; Kaplan, 1992).

Individuals were classified as hypertensive when they: (1) presented systolic pressure $\geq$ $140 \mathrm{mmHg}$ and/or diastolic pressure $\geq 90 \mathrm{mmHg}$ 
(JNC V, 1993) and/or (2) reported using medication for hypertension in the last 90 days. Use of antihypertensive medication was defined by linking the response to the question "Are you using antihypertensive medication?", asked before measuring blood pressure, to the information obtained by inspecting the packaging from medicines used in the last 90 days, at the time of the home interview (Barreto et al., 2001). Medications used to control blood pressure were classified as those containing at least one of the following substances: beta-blockers, diuretics, calcium channel blockers, ACE inhibitors, ACE antagonists, central alpha-blockers, and/or vasodilators.

\section{Anthropometric measurements}

Anthropometric measurements were performed with the individual wearing light clothing and were taken by specially trained technicians, under the supervision of a nutritionist. Two digital scales and two anthropometers were used, with the following specifications: High Precision Digital Scale (range 0-150kg x 0.1kg) and Portable Stadiometer kit (CMS Weighing Equipment Ltd, United Kingdom). Body mass index (BMI) (weight/height squared) was used for the present study.

\section{Serology for Trypanosoma cruzi}

Presence of antibodies to T. cruzi was determined by means of indirect hemagglutination reaction (IHA) and ELISA (Biolab and Abbott Brazil, respectively). Individuals presenting antibodies in both tests were classified as positive.

\section{Data analysis}

We compared the characteristics of individuals with and without a report of treatment for arterial hypertension (Figure 1). Bivariate data analysis was based on Pearson's $\chi^{2}$ or the linear trend $\chi^{2}$ test (Armitage \& Berry, 1987).

Multivariate analysis used the multiple logistic regression method (Hosmer \& Lemenshow, 1989). Odds ratios (OR) and respective confidence intervals were obtained by Wolff's method (Schlesselman, 1982). The criterion for inclusion of a variable in the logistic model was association with treatment for hypertension according to the univariate analysis at $\mathrm{p}<0.20$ (Greenland, 1989). All variables associated with treatment of hypertension at a level below 0.05 were maintained in the final model. Analyses were performed using the Stata software.

\section{Results}

Of the 1,494 older adults with blood pressure measurements, $919(61.5 \%)$ were classified as hypertensive. From this total, 704 (76.6\%) were aware of their condition and were included in this study. Only 126 (17.9\%) individuals who were aware of their condition were not being treated for hypertension.

Among the 578 older adults under treatment, 224 (38.8\%) presented systolic pressure $<140 \mathrm{mmHg}$ and diastolic pressure $<90 \mathrm{mmHg}$, 200 (34.6\%) displayed systolic pressure from 140 to $159 \mathrm{mmHg}$ and/or diastolic pressure from 90 to $99 \mathrm{mmHg}$, and 154 (26.6\%) presented systolic pressure $\geq 160$ and/or diastolic pressure $\geq 100 \mathrm{mmHg}$.

Table 1 shows the distribution of hypertensive older adults according to treatment status and socio-demographic characteristics. Only gender and monthly family income were significantly associated with treatment of hypertension in the univariate analysis. No statistical association was encountered with marital status, age group, living alone, and the need for a proxy respondent during the interview.

Factors significantly associated with the treatment of arterial hypertension included: (1) less time elapsed since the last blood pressure measurement; (2) more physician consultations in the last 12 months; (3) more medications used in the last 90 days; (4) prior medical diagnosis of angina pectoris or myocardial infarction; (5) prior medical diagnosis of diabetes; and (6) family history of cardiovascular disease before the age of 50 . The number of hospital admissions in the last 12 months, access to a private health care plan, and presence of antibodies to T. cruzi were not associated significantly with treatment of hypertension (Table 2).

Table 3 shows the distribution of older adults according to antihypertensive treatment and habits. Treatment of hypertension was significantly associated with current smoking, daily consumption of fresh fruit and vegetables in the last 12 months, attempts to lose weight due to health problems in the last 12 months, diet changes due to hypertension in the last 12 months, and BMI. Physical activity during leisure time in the last 90 days was not significantly associated with the treatment of hypertension.

Table 4 shows factors significantly $(\mathrm{p}<0.05)$ associated with current treatment of hypertension according to the multivariate analysis. Treatment of hypertension was independently associated with the following variables, in decreasing order of magnitude: less than one year 
elapsed since the last blood pressure measurement (OR $=4.25$; 95\% CI: 1.99-9.52); four or more medical consultations in the last 12 months $(\mathrm{OR}=2.68$; 95\% CI: $1.30-5.51)$; $\mathrm{BMI}=$ $25-29(\mathrm{OR}=2.02 ; 95 \%$ CI: $1.26-3.22)$ and $\geq 30 \mathrm{~kg} / \mathrm{m}^{2}$ $(\mathrm{OR}=2.66 ; 95 \% \mathrm{CI}: 1.37-5.18)$; female gender $(\mathrm{OR}=2.37 ; 95 \% \mathrm{CI}: 1.52-3.70)$; prior medical diagnosis of angina pectoris or myocardial infarction $(\mathrm{OR}=2.32 ; 95 \% \mathrm{CI}$ : 1.03-5.24); diet changes due to hypertension in the last 12 months (OR $=2.04$; 95\% CI: 1.08-3.85); and monthly family income $\geq$ four times the prevailing Brazilian minimum wage $(\mathrm{OR}=1.79$; 95\% CI: 1.03-3.13).

\section{Discussion}

Our results showed a high proportion of untreated older adults with hypertension (37\%) and of individuals with uncontrolled blood pressure despite treatment $(61 \%)$, assuming controlled systolic and diastolic pressure as 140 and $90 \mathrm{mmHg}$, respectively. Use of the 160 and $95 \mathrm{mmHg}$ cut-offs increased the percentage of controlled hypertension to $73 \%$. Despite some differences in methodology, these observations are consistent with results of studies conducted among older adults living in three small Italian cities (Prencipe et al., 2000); in Jerusalem (Burcztyn et al., 1996); and among older Mexican-Americans residing in five States in the United States (Satish et al., 1998). About one fourth of the older adults residing in Bambuí were unaware of their hypertension. This proportion was similar to that observed among older adults in Poland and Spain (Compãn et al., 1998; Krupa-Wojciechowska et al., 1996) and lower than that observed among Israelis, Italians, Americans, and Germans (Bursztyn et al., 1996; Prencipe et al., 2000; Satish et al., 1998; Trenkwalder et al., 1994). The high proportion of older adults in Bambui who had had their blood pressure measured during the last year (87\%) (Lima-Costa et al., 2001a) at least partially explains why awareness of hypertension was higher in Bambuí than in the majority of the studies mentioned above.

Research on factors associated with the treatment of hypertension among older adults in communities is rare. According to a study in New York involving 1,394 volunteers, age, BMI, and number of physician consultations were positively and independently associated with treatment of hypertension (Stockwell et al., 1994). Another study, conducted in a representative sample of 3,050 Mexican-Americans (65 years or older) residing in five U.S. States,

\begin{tabular}{|c|c|c|c|}
\hline \multicolumn{4}{|c|}{$\begin{array}{l}\text { Distribution of hypertension among older adults according to treatment } \\
\text { status and selected socio-demographic characteristics, Bambuí, Minas Gerais } \\
\text { State, Brazil, } 1997 .\end{array}$} \\
\hline \multirow[t]{2}{*}{ Variables } & \multicolumn{2}{|c|}{ Treatment } & \multirow[b]{2}{*}{$\mathrm{p}$ value } \\
\hline & $\begin{array}{l}\text { Yes }(\%) \\
(n=578)\end{array}$ & $\begin{array}{c}\text { No }(\%) \\
(n=126)\end{array}$ & \\
\hline \multicolumn{4}{|l|}{ Age group (years) } \\
\hline $60-69$ & 59.9 & 57.9 & \\
\hline $70-79$ & 32.2 & 32.6 & \\
\hline$\geq 80$ & 7.9 & 9.5 & 0.829 \\
\hline \multicolumn{4}{|l|}{ Gender } \\
\hline Male & 24.4 & 51.6 & \\
\hline Female & 75.6 & 48.4 & $<0.001$ \\
\hline \multicolumn{4}{|l|}{ Marital status } \\
\hline Married/living together & 45.5 & 54.0 & \\
\hline Single/divorced/separated & 14.5 & 15.9 & \\
\hline Widowed & 40.0 & 30.2 & 0.116 \\
\hline \multicolumn{4}{|l|}{ Living alone } \\
\hline No & 18.4 & 17.5 & \\
\hline Yes & 81.6 & 82.5 & 0.804 \\
\hline \multicolumn{4}{|l|}{ Mean monthly family income** } \\
\hline$<2$ & 28.5 & 37.4 & \\
\hline $2-3.99$ & 37.7 & 36.6 & \\
\hline$\geq 4$ & 33.8 & 26.0 & $0.033^{*}$ \\
\hline \multicolumn{4}{|l|}{$\begin{array}{l}\text { Proxy respondent during } \\
\text { the interview }\end{array}$} \\
\hline No & 96.5 & 96.8 & \\
\hline Yes & 3.5 & 3.2 & 0.873 \\
\hline $\begin{array}{l}\mathrm{p}=\text { Pearson's } \chi^{2} \text { test } \\
{ }^{\star} \chi^{2} \text { test for linear trend } \\
\star \star T \text { Times Brazilian minimum wag } \\
(1 \text { minimum wage }=\mathrm{R} \$ 120.00)\end{array}$ & he of the & & \\
\hline
\end{tabular}

showed that treatment of hypertension was independently associated with more physician consultations in the last year, existence of a regular source of medical care, female gender, living alone, and history of diseases or selected chronic conditions (heart disease, diabetes, and better performance in the mini-mental test) (Satish et al., 1998).

Factors associated with treatment of hypertension among older adults in Bambuí were very similar to those observed in the studies quoted above. The strongest associations were for frequency of physician consultations (i.e., more visits) and less time elapsed since last measurement of blood pressure. In addition to these factors, treatment of hypertension was independently associated with higher BMI, 
Table 2

Distribution of hypertension among older adults according to treatment status and selected indicators of health conditions, health care, and use of medication, Bambuí, Minas Gerais State, Brazil, 1997.

\begin{tabular}{|c|c|c|c|}
\hline \multirow[t]{2}{*}{ Variables } & \multicolumn{2}{|c|}{ Treatment } & \multirow[b]{2}{*}{$p$ value } \\
\hline & $\begin{array}{c}\text { Yes (\%) } \\
(n=578)\end{array}$ & $\begin{array}{c}\text { No (\%) } \\
(n=126)\end{array}$ & \\
\hline \multicolumn{4}{|c|}{$\begin{array}{l}\text { Time elapsed since last measurement of blood } \\
\text { pressure (years) }\end{array}$} \\
\hline$\geq 1$ & 2.6 & 19.1 & \\
\hline$<1$ & 97.4 & 80.9 & $<0.001$ \\
\hline \multicolumn{4}{|c|}{ Number of physician visits in the last 12 months } \\
\hline 0 & 8.0 & 23.8 & \\
\hline $1-3$ & 51.2 & 55.6 & \\
\hline$\geq 4$ & 40.8 & 20.6 & $<0.001^{*}$ \\
\hline \multicolumn{4}{|c|}{ Number of hospital admissions in the last 12 months } \\
\hline 0 & 75.8 & 79.4 & \\
\hline 1 & 15.9 & 15.1 & \\
\hline$\geq 2$ & 8.3 & 5.5 & 0.291 * \\
\hline \multicolumn{4}{|c|}{$\begin{array}{l}\text { Number of medication used in the last } 90 \text { days } \\
\text { (except antihypertensive medication) }\end{array}$} \\
\hline 0 & 13.8 & 25.4 & \\
\hline $1-2$ & 36.7 & 42.9 & \\
\hline $3-4$ & 31.5 & 19.8 & \\
\hline$\geq 5$ & 18.0 & 11.9 & $<0.001^{\star}$ \\
\hline \multicolumn{4}{|c|}{ Access to private health care plan } \\
\hline No & 77.5 & 81.7 & \\
\hline Yes & 22.5 & 18.3 & 0.296 \\
\hline \multicolumn{4}{|c|}{ Prior medical diagnosis of angina pectoris } \\
\hline \multicolumn{4}{|c|}{ or myocardial infarction } \\
\hline No & 82.7 & 93.6 & \\
\hline Yes & 17.3 & 6.4 & 0.002 \\
\hline \multicolumn{4}{|c|}{ Prior medical diagnosis of diabetes } \\
\hline No & 83.7 & 91.3 & \\
\hline Yes & 16.3 & 8.7 & 0.030 \\
\hline \multicolumn{4}{|c|}{$\begin{array}{l}\text { Family history of cardiovascularm disease before } \\
\text { the age of } 50\end{array}$} \\
\hline No & 46.2 & 62.5 & \\
\hline Yes & 53.8 & 37.5 & 0.001 \\
\hline \multicolumn{4}{|c|}{ Antibodies to T. cruzi } \\
\hline No & 61.5 & 56.4 & \\
\hline Yes & 38.5 & 43.6 & 0.281 \\
\hline
\end{tabular}

$\mathrm{p}=$ Pearson's $\chi^{2}$ test

${ }^{\star} \chi^{2}$ test for linear trend 


\begin{tabular}{|c|c|c|c|}
\hline \multirow[t]{2}{*}{ Variables } & \multicolumn{2}{|c|}{ Treatment } & \multirow[b]{2}{*}{$p$ value } \\
\hline & $\begin{array}{l}\text { Yes }(\%) \\
(n=578)\end{array}$ & $\begin{array}{l}\text { No }(\%) \\
(n=126)\end{array}$ & \\
\hline \multicolumn{4}{|c|}{ Current smoking } \\
\hline No & 87.7 & 73.8 & \\
\hline Yes & 12.3 & 26.2 & $<0.001$ \\
\hline \multicolumn{4}{|c|}{$\begin{array}{l}\text { Daily consumption of fresh fruit and vegetables } \\
\text { in the last } 12 \text { months }\end{array}$} \\
\hline No & 45.8 & 64.3 & \\
\hline Yes & 54.2 & 35.7 & $<0.001$ \\
\hline \multicolumn{4}{|c|}{ Physical activity during leisure time* in the last 90 days } \\
\hline No & 88.9 & 86.2 & \\
\hline Yes & 11.1 & 13.8 & 0.414 \\
\hline \multicolumn{4}{|c|}{$\begin{array}{l}\text { Attempts to lose weight due to health problems } \\
\text { in the last } 12 \text { months }\end{array}$} \\
\hline No & 74.7 & 86.5 & \\
\hline Yes & 25.3 & 13.5 & 0.005 \\
\hline \multicolumn{4}{|c|}{$\begin{array}{l}\text { Changes in diet due to hypertension in the last } \\
12 \text { months }\end{array}$} \\
\hline No & 73.2 & 89.7 & \\
\hline Yes & 26.8 & 10.3 & $<0.001$ \\
\hline \multicolumn{4}{|c|}{ Body mass index } \\
\hline$\leq 24$ & 25.3 & 48.4 & \\
\hline $25-29$ & 49.5 & 39.7 & \\
\hline$\geq 30$ & 25.2 & 11.9 & $<0.001$ \\
\hline
\end{tabular}

$\mathrm{p}$ : Pearson's $\chi^{2}$ test

* 20-30 minutes, 3 or more times per week

coronary disease, diet changes due to hypertension, higher family income, and female gender. Higher BMI may increase the perception of the need for treatment, since the coexistence of hypertension with obesity increases the risk of cardiovascular events (Kannel, 1997, 2000). Irrespective of the severity of a patient's condition, coronary disease, which is a cardiovascular ailment, tends to encourage patients to adhere to treatment regimens, while medical services are more likely to monitor these individuals more closely. Diet changes due to hypertension possibly reflect a tendency of treated individuals to also attempt complementary treatment methods, such as diet control. Diet changes due to hypertension also reflect the association identified in the univariate analysis with the variables "consumption of fresh fruit and vegetables" and "attempts to lose weight due to health problems", which express the same behavior. The associations between the latter two variables and treatment of hypertension disappeared in the multivariate analysis due to colinearity with the variable "diet change due to arterial hypertension”. The absence of an association between physical activity and treatment of hypertension in the analysis could reflect the difficulty of older individuals to perform physical activity according to the recommended patterns: exercise on a level surface, in the shade, and in some cases with a companion. The association with higher family income possibly indicates better access to health services (Lima-Costa et al., submitted). It has been consistently demonstrated that women are more likely to be aware of their hypertension, to be treated, and to have better control of their hypertension than men (Bursztyn et al., 1996; Joffres et al., 1997; Plasencia et al., 1988; Satish et al., 1998, 1997). In the present study, female 
Table 4

Final results of multivariate analysis of factors associated with treatment of hypertension among older adults, Bambuí, Minas Gerais State, Brazil, 1997.

\begin{tabular}{|c|c|}
\hline Variables & OR $(95 \% \mathrm{Cl})$ \\
\hline \multicolumn{2}{|c|}{$\begin{array}{l}\text { Time elapsed since last measurement } \\
\text { of blood pressure (in years) }\end{array}$} \\
\hline$\geq 1$ & 1.00 \\
\hline$<1$ & $4.25(1.99-9.52)$ \\
\hline \multicolumn{2}{|c|}{ Number of doctor visits in the last 12 months } \\
\hline 0 & 1.00 \\
\hline $1-3$ & $1.50(0.80-2.83)$ \\
\hline$\geq 4$ & $2.68(1.30-5.51)$ \\
\hline \multicolumn{2}{|c|}{ Body mass index $\left(\mathrm{kg} / \mathrm{m}^{2}\right)$} \\
\hline$\leq 24$ & 1.00 \\
\hline $25-29$ & $2.02(1.26-3.22)$ \\
\hline$\geq 30$ & $2.66(1.37-5.18)$ \\
\hline \multicolumn{2}{|l|}{ Gender } \\
\hline Male & 1.00 \\
\hline Female & $2.37(1.52-3.70)$ \\
\hline \multicolumn{2}{|c|}{$\begin{array}{l}\text { Prior medical diagnosis of angina pectoris } \\
\text { and/or myocardial infarction }\end{array}$} \\
\hline No & 1.00 \\
\hline Yes & $2.32(1.03-5.24)$ \\
\hline \multicolumn{2}{|c|}{$\begin{array}{l}\text { Changes in diet because of hypertension } \\
\text { in the last } 12 \text { months }\end{array}$} \\
\hline No & 1.00 \\
\hline Yes & $2.04(1.08-3.85)$ \\
\hline \multicolumn{2}{|c|}{$\begin{array}{l}\text { Monthly family income (in times Brazilian } \\
\text { minimum wage) }\end{array}$} \\
\hline$<2$ & 1.00 \\
\hline $2-3.99$ & $1.43(0.86-2.38)$ \\
\hline$\geq 4$ & $1.79(1.02-3.13)$ \\
\hline
\end{tabular}

OR $(95 \% \mathrm{Cl})=$ Odds Ratio (at 95\% confidence level) adjusted for all the variables listed in the table, using multiple logistic regression (704 individuals participated in the final analysis). with a longer lifespan (Kannel, 1996), we could expect an increase in the prevalence of treatment in older individuals. However, in this study we did not identify an association between age and treatment, making cross-sectional bias unlikely. One possible limitation of the study refers to the way by which information on treatment of hypertension was obtained (by means of an interview). Some studies show that information provided by patients on the use of medications may result in overestimates of adherence to treatment regimens (Enlund et al., 1981; Haynes et al., 1989; Merino et al., 1993), although others have shown that a good correlation exists between patients' reports of treatment on different occasions (test and re-test) (Coutinho et al., 1999), between the patients' reports and the number of pills counted or presence of drugs in the urine (Black et al., 1987; Guerrero et al., 1993).

The identification and adequate treatment of older adult residents with hypertension in the community remain a challenge for public health care. For a long time it was believed that the risk factors for chronic non-communicable diseases were public health problems only in large cities of Brazil, and that small municipalities should concentrate their efforts on controlling infectious diseases (Lima-Costa et al., 2001a). Our results show that older adult residents of a small city in Minas Gerais showed a high prevalence of hypertension and that nearly $25 \%$ of the elderly were unaware of their condition. The high proportion of older adults who were unaware of their hypertension in Bambuí town is similar to that observed among older adults in Poland and Spain (Compãn et al., 1998; Krupa-Wojciechowska et al., 1996). This finding suggests difficulties in access to and/or under-utilization of health services and merit further investigation. Our results indicate precarious control of hypertension among older people who were being treated. Considering $140 / 90 \mathrm{mmHg}$ as the blood pressure parameters, the percentage of individuals with adequate control (39\%) is lower than that recommended by the American Health People 2000, objective $15.4(50 \%)$. It is important to note that the control of hypertension in this study may be overestimated because it was limited to those individuals who knew they were hypertensive.

In summary, our results show that factors independently associated with treatment of hypertension reflect better access to and/or utilization of health services (time elapsed since the last measurement of blood pressure, number of physician consultations in the last 
year, family income), the existence of co-morbidities (BMI and prior medical diagnosis of angina pectoris and/or myocardial infarction), and gender. The higher prevalence of antihypertensive treatment among women is consistent with their behavior in relation to other health care indicators, such as healthy diet and less smoking and alcohol consumption (Kami-

\section{Acknowledgments}

The authors wish to acknowledge the contributions from the following members of the BHAS Group: E. Uchôa, H. L. Guerra, P. G. Vidigal, and V. M. A. Passos. The study was supported by the Funding Agency for Studies and Projects (FINEP), Brazil. M. F. Lima-Costa and S. M. Barreto are fellows of the National Research Council (CNPq), Brazil. This study would not have been possible without the collaboration of the population of Bambuí.

\section{References}

AMERY, A.; BIRKENHAGER, W.; BRIXKO, P.; BULPITT, C.; CLEMENT, D.; DERUYTTERE, M.; SCAEPDRYVER, A.; DOLLERY, C.; FAGARD, R.; FORETTE, F.; HAMDY, R.; JOOSENS, J. V.; LUNDJOHANSEN, P.; PETRIE, J. \& WILLIANS, B., 1985. Morbidity and mortality results from the European Working Party on High Blood Pressure in the Elderly. Lancet, 1:1349-1354.

ARMITAGE, P. \& BERRY, G., 1987. Statistical Methods in Medical Research. Scientific Publications 125128. Oxford: Blackwell Publishers.

BARRETO, S. M.; PASSOS, V. M. A.; FIRMO, J. O. A.; GUERRA, H. L.; VIDIGAL, P. G. \& LIMA-COSTA, M. F. F., 2001. Hypertension and clustering of cardiovascular risk factors in a community in Southeast Brazil - The Bambuí Health and Ageing Study. Arquivos Brasileiros de Cardiologia, 6:576-581.

BLACK, D. M.; BRAND, R. J.; GREENLICK, M.; HUGHES, G. \& SMITH, J., 1987. Compliance to treatment for hypertension in elderly patients: The SHEP pilot study. Systolic Hypertension in the Elderly Program. Journal of Gerontology, 42:552557.

BURSZTYN, M.; SHPILBERG, O.; GINSBERG, G. M.; COHEN, A. \& STESSNAN, J., 1996. Hypertension in the Jerusalem 70 year olds study population: Prevalence, awareness, treatment and control. Israel Journal of Medical Sciences, 32:629-633. moto et al., 1999). Note that the factor most strongly associated with treatment of hypertension in the present study (use of health services) could be modified through adequate health policies for older adults. Further studies are needed to determine whether our results could be applied to other small cities in Brazil.

COMPAÑ, L.; VIOQUE, J.; HERNANDEZ-AGUADO, I. \& QUILES, J., 1998. Factores asociados al conocimiento, tratamiento y control de la hipertensión arterial en población adulta de la Comunidad Valenciana. Atención Primaria, 21:527-533.

COUTINHO, E. S. F.; SILVA, S. D.; PAIVA, C. H. A.; FREITAS, G. G.; MIRANDA, L. P. \& MENDONÇA, R., 1999. Confiabilidade da informação sobre uso recente de medicamentos em um estudo casocontrole de base hospitalar. Cadernos de Saúde Pública, 15:553-558.

DALHOF, B.; LINDHOLM, L. H.; HANSSON, L.; SCHERSTEN, B.; TORD, E. \& WESTER, P.-O., 1991. Morbidity and mortality in the Swedish Trial in Old Patients with Hypertension (STOP-Hypertension). Lancet, 338:1281-1285.

DE BACKER, G.; MYNY, K.; DE HENAUW, S.; DOYEN, Z.; VAN OYEN, H.; TAFFOREAU, J. \& KORNITZER, M., 1998. Prevalence, awareness, treatment and control of arterial hypertension in an elderly population in Belgium. Journal of Human Hypertension, 12: 701-706.

DE LENA, S.; CINGOLANI, H. E.; ALMIRON, M. A. \& ECHEVERRIA, R. F., 1995. Prevalencia de la hipertension arterial em uma población rural bonarense. Medicina, 55:225-230.

ENLUND, H.; TUOMILRHTO, J. \& TURAKKA, H., 1981. Patient report validated against records for 
measuring use of and compliance with antihypertensive drugs. Acta Medica Scandinava, 209: 271-275.

FREEMAN, V.; ROTIMI, C. \& COOPER, R., 1996. Hypertension prevalence, awareness, treatment, and control among African Americans in the 1990s: Estimates from the Maywood Cardiovascular Survey. American Journal of Preventive Medicine, 12:177-185.

IBGE (Fundação Instituto Brasileiro de Geografia e Estatística), 1992. Anuário Estatístico do Brasil. Censo Demográfico de 1992. Rio de Janeiro: Secretaria de Planejamento, Orçamento e Coordenação, IBGE.

IBGE (Fundação Instituto Brasileiro de Geografia e Estatística), 2000. Projeção Preliminar da População do Brasil por Sexo e Idades Simples: 19802050 - Revisão 2000. 7 Agosto $2001<$ http:www. ibge.gov.br>.

GREENLAND, S., 1989. Modeling and variable selection in epidemiologic analysis. American Journal of Public Health, 79:340-349.

GUERRERO, D.; RUDD, P.; BRYANT-KOSLING, C.; MIDDLETON, B. \& MIDDLETON, B. F., 1993. Antihypertensive medication-taking: Investigation of a simple regimen. American Journal of Hypertension, 6:586-591.

HAYNES, R. B.; SACKETT, D. L. \& TUGWELL, P., 1989. Cumplimiento. In: Epidemiología Clínica: Una Ciencia Básica para la Medicina Clínica (R. B. Haynes, D. L. Sackett \& P. Tugwell, org.), pp. 250290, Madrid: Diaz de Santos.

HOSMER, D. W. \& LEMENSHOW, S., 1989. Applied Logistic Regression. New York: Johns Wiley and Sons.

IBRAIM, M. M.; RIZK, H.; APPEL, L. J.; AROUSSY, W. E.; HELMY, S.; SHARAF, Y.; ZEINAB, A.; KANDIL, H.; ROCCELLA, W. E.; WHELTON, P. \& NHP INVESTIGATE TEAM, 1995. Hypertension prevalence, awareness, treatment, and control in Egypt. Hypertension, 26:886-890.

JNC (Joint National Committee), 1993. The fifth report of the Joint National Committee on Detection, Evaluation, and Treatment of High Blood Pressure (JNC V). Archives of Internal Medicine, 153:154-183.

JOFFRES, M. R.; GHARDIRIAN, P.; FODOR, J. G.; PETRASOVITS, A.; CHOCKALINGAM, A. \& HAMET, P., 1997. Awareness, treatment, and control of hypertension in Canada. American Journal of Hypertension, 10:1097-1102.

KAMIMOTO, L. A.; EASTON, A. N.; MAURICE, E.; HUSTEN, C. G. \& MACERA, C. A., 1999. Surveillance for five health risks among older adults United States, 1993-1997. MMWR, CDC Surveillance Summaries, 48(SS-8):89-130.

KANNEL, W. B., 1996. Cardioprotection and antihypertensive therapy: The key importance of addressing the associated coronary risk factors (The Framingham Experience). American Journal of Cardiology, 77:6B-11B.

KANNEL, W. B., 1997. Cardiovascular risk factors in the elderly. Coronary Artery Disease, 8:564-675.

KANNEL, W. B., 2000. Risk stratification in hypertension: New insights from the Framingham study. American Journal of Hypertension, 13:3S-10S.

KAPLAN, N. M., 1992. Systemic hypertension: Mech- anisms and diagnosis. In: Heart Disease: A Textbook of Cardiovascular Medicine (E. Braunwald, ed.), pp. 817-851, 4th Ed., Philadelphia:W. B. Saunders.

KRUPA-WOJCIECHOWSKA, B.; NARKIEWICZ, K. \& RYNKIEWICZ, A., 1996. Awareness and treatment of arterial hypertension in Poland. Journal of $\mathrm{Hu}$ man Hypertension, 10:S25-S27.

LIMA-COSTA, M. F; GUERRA, H. L.; BARRETO, S. M. \& GUIMARÃES, R. M., 2000a. Diagnóstico da situação de saúde da população idosa brasileira: Um estudo da mortalidade e das internações hospitalares públicas. Informe Epidemiológico do SUS, 9:23-41.

LIMA-COSTA, M. F. F.; BARRETO, S.; UCHOA, E.; FIRMO, J. O. A.; VIDIGAL, P. G. \& GUERRA, H. L., 2001a. The Bambuí Health and Aging Study (BHAS): Prevalence of risk factors and use of preventive health care services. Revista Panamericana de Salud Pública, 9:219-227.

LIMA-COSTA, M. F. F; BARRETO, S. M.; GUERRA, H. L.; FIRMO, J. O. A.; UCHOA, E. \& VIDIGAL, P. G., 2001b. Ageing with Trypanosoma cruzi infection in a community where the transmission has been interrupted: The Bambuí Health and Ageing Study (BHAS). International Journal of Epidemiology, 30:887-893.

LIMA-COSTA, M. F. F.; UCHÔA, E.; GUERRA, H. L.; FIRMO, J. O. A.; VIDIGAL, P. G. \& BARRETO, S. M., 2000b. The Bambuí Health and Ageing Study (BHAS). Methodological approach and preliminary results of a population-based cohort study of the elderly in Brazil. Revista de Saúde Pública, 34:126-135.

LIMA-COSTA, M. F.; UCHOA, E.; BARRETO, S. M.; FIRMO, J. O. A. \& THE BHAS GROUP, submitted. An ethnoepidemiologic study on socioeconomic position and health among Brazilian elderly: The Bambuí Health and Ageing Study (BHAS). Revista Panamericana de Salud Pública.

MERINO, J.; GIL, V. \& BELDA, J., 1993. Métodos de conocimiento y medida de la observancia. In: $L a$ Observancia en el Tratamiento de la HTA (A. Martinez-Amenos, org.), pp. 7-31, Barcelona: Doyma SA.

MRC WORKING PARTY, 1992. Medical research council trial of treatment of hypertension in older adults: Principal results. BMJ, 304:405-412.

NATIONAL CENTER FOR HEALTH STATISTICS, 1999. Health People 2000. Review, 1998-99. Hyattsville: Public Health Service.

NATIONAL HIGH BLOOD PRESSURE EDUCATION PROGRAM WORKING GROUP, 1994. National High Blood Pressure Education Program Working Group in the Elderly. Hypertension, 23:275-285.

PICCINI, R. X. \& VICTORA, C. G., 1994. Hipertensão arterial sistêmica em área urbana no sul do Brasil: Prevalência e fatores de risco. Revista de Saúde Pública, 28:261-267.

PLASENCIA, A.; OSTFELD, A. M. \& GRUBER, S. B. 1988. Effects of sex on differences in awareness, treatment, and control of high blood pressure. American Journal of Preventive Medicine, 4:315326.

PRENCIPE, M.; CASINI, A. R.; SANTINI, M.; FERRETI, C.; SCALDAFERRI, N. \& CULASSO, F., 2000. Prevalence, awareness, treatment and control of hy- 
pertension in the elderly: Results from a population survey. Journal of Human Hypertension, 14:825-830.

OMS (Organização Mundial da Saúde), 1995. Classificação Estatística Internacional de Doenças e Problemas Relacionados à Saúde, 10a Revisão. v. 1. São Paulo: Centro Colaborador da OMS para a Classificação de Doenças em Português.

RUDD, P., 1995. Clinicians and patients with hypertension: Unsettled issues about compliance. Journal of the American Heart Association, 130:572579.

SATISH, S.; MARKIDES, K. S.; ZHANG, D. \& GOODWIN, J. S., 1997. Factors influencing unawareness of hypertension among older Mexican Americans. Preventive Medicine, 26:645-650.

SATISH, S.; STROUP-BENHAM, C. A.; ESPINO, D. V.; MARKIDES, K. S. \& GOODWIN, J. S., 1998. Undertreatment of hypertension in older Mexican Americans. Journal of American Geriatrics Society, 46:405-410.

SCHLESSELMAN, J. J., 1982. Case Control Studies. Design, Conduct, Analysis. New York: Oxford University Press.

SHEP COOPERATIVE RESEARCH GROUP, 1991. Prevention of stroke by antihypertensive drug treatment in older persons with isolated systolic hypertension. JAMA, 265:3255-3264.

SRINIVAS, P.; WONG, K. S.; CHIA, Y. C.; POI, P. J. H. \& EBRAHIM, S., 1998. A profile of hypertension among rural elderly Malaysians. Southeast Asian Journal of Tropical Medicine and Public Health, 29:821-826.
STOCKWELL, D. H.; MADHAVAN, S.; COHEN, H.; GIBSON, G. \& ALDERMAN, M. H., 1994. The determinants of hypertension awareness, treatment, and control in an insured population. American Journal of Public Health, 84:1768-1774.

TRENKWALDER, P.; RULAND, D.; STENDER, M.; GEBHARD, J.; TRENKWALDER, C.; LYDTIN, H. \& HENSE, H. W., 1994. Prevalence, awareness, treatment and control of hypertension in a population over the age of 65 years: results from Starnberg Study on Epidemiology of Parkinsonism and Hypertension in the Elderly (STEPHY). Journal of Hypertension, 12:709-716.

TRINDADE, I. S.; HEINECK, G.; MACHADO, J. R.; AYZEMBERG, H.; FORMIGHIERI, M. \& CRESTANE, M., 1998. Prevelência da hipertensão arterial sistêmica na população urbana de Passo Fundo (RS). Arquivos Brasileiros de Cardiologia, 71:127130.

UN (United Nations), 1985. The World Aging Situation: Strategies and Policies. Technical Report. New York: Department of Economic and Social Affairs, UN.

VOKONAS, P. S.; KANNEL, W. B. \& CUPPLES, L. A., 1988. Epidemiology and risk of hypertension in the elderly: The Framingham Study. Journal of Hypertension, 6:S3-S9.

Submitted on February 7, 2002

Final version resubmitted on July 12, 2002

Approved on August 27, 2002 